\title{
Operating Cash Flow and Dividend Changes as a Management Tool for Planning and Making Decision
}

\author{
Associate Professor Faris Alqadi \\ Accounting Department, Jarash University \\ Tel: 96-27-9639-9989Ｅ-mail: faris.1965@hotmail.com
}

Received: June 5, 2020 Accepted: July 27, $2020 \quad$ Published: December 1, 2020

doi:10.5296/ajfa.v12i2.17310 URL: https://doi.org/10.5296/ajfa.v12i2.17310

\begin{abstract}
The main objective of this study was to examine whether operating cash flows have incremental information beyond operating net income in explaining dividend changes for a sample of Jordanian industrial firms listed on the Amman Stock Exchange (ASE) during the period 2010-2016 Arguments for operating cash flow information suggest that it is better than accrual net income in reflecting the firm performance and in measuring the firm liquidity. Both performance and liquidity are viewed as significant factors influencing a firm's dividend policy. To examine this, operating cash flow, operating net income and lagged dividends were incorporated in a regression model. The results of this model indicated that the only significant variables explaining dividend changes were operating net income and lagged dividends with positive and negative coefficients, respectively. An attempt was also made to address the problem of nonlinearity in the relationship between cash flow and dividend changes. The sample of the industrial firms were divided into two groups (high growth and low growth firms) based on market to book value ratio. The results of the two regression models provided evidence consistent with the superiority of accrual operating net income over operating cash flow in explaining dividend changes. The results of this study suggest that Jordanian industrial firms base their dividend policies on accrual net income rather than on cash flows. One possible consequence of this suggestion is that cash dividends are not internally financed and as a result, this would deteriorate the liquidity and solvency position of a firm.
\end{abstract}

Keywords: Operating cash flow, Dividend changes, Operating net income, Amman stock exchange (ASE) 


\section{Introduction}

Interest in cash flow reporting has increased in recent years. Realizing the usefulness of cash flow information, regulatory bodies in most countries, including Jordan, and the International Accounting Standards Committee (IASC) require companies to prepare a statement of cash flows as part of their reporting system. Several studies have attempted to compare the usefulness of cash flow information with that of accrual income. For example, Dechow found that accrual income was more closely related to firm performance (as reflected in stock returns) than cash flow from operations. On the other hand, Sloanfound that the levels of cash flow achieved are more likely to continue in the future, while the accrual components of income are temporary and likely to be reversed. In addition, several studies linked cash flow information with dividends. They assume that cash flows have superiority over accrual income in explaining dividend changes. Two possible explanations are provided to support this superiority. First, the amount and timing of net income is subject to management discretion and manipulation, and is also based on estimates that change over time. For instance, management may overstate accrual income to increase their compensations or to satisfy debt covenants. Thus, if a firm's dividend policy is assumed to reflect the firm's performance, cash flow components of income could be a better indicator of a firm's performance than accrual components, and as a result, a better predictor of a firm's dividend changes. Second, compared with accrual income, cash flow is a more direct measure of liquidity. Liquidity is considered an important determinant of a firm's dividend policy.

\section{Statement of the Problem}

The main objectives of this study is to examine whether operating cash flows have incremental information beyond operating net income in explaining dividend changes. Specifically, this study examines the impact of operating cash flow, given net income, on the dividend changes of a sample of 42 Jordanian industrial companies listed on the Amman Stock Exchange (ASE) during the period 2010-2016. In addition, the study will attempt to address the problem of nonlinearity in the relationship between cash flows and dividend changes depends on each firm's growth opportunities. We hypothesize that high growth firms are expected to have a lower cash flow- dividend relations ship than that for low growth firms.

Although previous research has examined similar questions to the ones addressed by the current study, no prior study, as far as this author is aware, has investigated them in Jordan. Thus, the current study is expected to enhance our understanding of the importance given by the management of Jordanian industrial firms to operating cash flows and operating net income in setting their dividend policies. Advocates of cash flow reporting argue that basing dividends on accrual net income rather than on cash flows would result in paying cash dividends that are not internally financed. Consequently, this would deteriorate both the liquidity and solvency position of a firm.

The remaining part of this study is organized as follows. The following section provides a review of related literature. Section 5 develops testable hypotheses concerning the relationship between operating cash flows and dividend changes. Section 6 describes the 
research methodology and design. Section 7 presents the results of the study and section 8 summarizes the study and provides its main conclusions.

\section{Extant literature}

Substantial theoretical research supports the notion that corporate dividend policy is designed to reveal information about expected levels of a firm's future cash flows and /or earnings. However, empirical research on the association between dividend changes and cash flows has been inconclusive. Lintner found that current net earnings and prior year dividends are the most important variables determining dividend changes. Hagerman and Huefiner, Baker, and Pruitt and Gitman also reported similar results. Hagerman and Huefner, for instance, found that net income is a better determinant of dividend changes than cash flows. These studies were criticized on the ground that they defined cash flows as the net income plus depreciation which may be considered as a profitability measure rather than a liquidity measure. Thus, Simonsused three measures of cash flows; cash flow from operations, net current operating funds and total cash flow before dividends. Each measure of cash flows was incorporated into a regression model, which also included the net income and previous year dividends. The results of the study indicated that the only significant variables explaining dividend changes were the net income and previous year dividend with positive and negative coefficients respectively. Simons concluded that none of the three measures of cash flows added an incremental value to the net income and previous dividends explaining dividend changes. In another study, Benartzi et al., based on an extensive empirical analysis of dividend changes, concluded that “...Lintner's model of dividends remains the best description of the dividend setting process available." (p. 1032) In contrast, a study by Lipson et al. found that dividend initiation was not followed by an increase in firm earnings.

Ettredge and Kim extended previous research by investigating the impact of the adoption of last- in-first-out (LIFO) inventory pricing method in periods of inflation on changes in cash dividends. The adoption of LIFO in such periods depresses reported net income below the level that would have been reported without LIFO adoption and increases cash flows through the postponement of taxes to future periods. The results of the study indicated that the changes in cash dividends in the year of adoption were positively associated with the negative net income effect rather than the positive cash flow effect of LIFO adoption.

A recent study by Charitou and Vafeas examined the impact of operating cash flows and operating net income on dividend changes. They found that the net income is significantly and positively related to dividend changes while cash flow is not. They also found that previous year dividends are significantly and negatively associated with dividend changes. However, when the sample of firms was divided into five groups based on the size of cash flows, they found that cash flow from operations was an important variable in explaining dividend changes for those firms with relatively low cash flows. They concluded that for those firms cash flow acts as a constraint on their ability to pay dividends. In another study, Brook et al. attempted to answer the question whether firms use dividends to signal large future cash flow increases. They divided their sample of firms into three groups. The first included those firms which experienced permanently increased cash flows, the second 
included those firms which had temporary increased cash flows, and the third included firms which experienced a continued period of flat cash flow. The results of the study indicated that the average dividend increase in the group of firms which experienced permanently increased cash flows, was higher than the average dividend increase offered by the other two groups. The study also indicated that dividend decisions are made to signal positive information about permanent future cash flow levels rather than about future income changes.

The studies by Charitou and Vafeas and Brook et al. suggest that the relative benefits of accruals versus cash flows in explaining dividend changes may be firm - specific. For instance, Bernard and Stober pointed out that the variation in cash flow results found by some studies might be caused by using models, which were unable to capture the specific characteristics of any particular firm or situation. They indicated that the information content of cash flows versus accruals might be firm- industry-, and /or situation - specific. The current study will take into account the industry factor by concentrating only on the industrial firms listed on the Amman Stock Exchange. Also an attempt is made to examine the impact of the firm's growth prospects on the incremental information of cash flows.

\subsection{Conceptual Review (define and explain all the variables used in the study)}

As discussed earlier in the study, two plausible explanations are provided to support the superiority of operating cash flows over accrual income in explaining dividend changes. First, the accrual income is subject to manipulation caused by the recognition, estimation and measurement criteria employed in its determination. Management may manipulate the net income to boost their compensation. To the extent that this manipulation occurs, cash flow from operations provides a better measure of a firm's performance than the accrual income. In support of this reasoning, Bernstein states that, (p. 461):

Cash flow operations, as a measure of performance, is less subject to distortion than is the net income figure. This is so because the accrual system, which produces the income number, relies on accruals, deferrals, allocations and valuations, all of which involve higher degree of subjectivity than what enters the determination of cash flow from operations.

Similar reasoning was also advanced by the Financial Accounting Standard Board (FASB) as a justification for requiring firms to concentrate on cash flows information in their reporting system.

Second, one of the important determinants of dividends is liquidity. In this regard, profitability does not necessarily mean liquidity or the availability of cash. Consequently, cash flow is considered a more direct measure of liquidity compared to the accrual income.

Based on the above reasoning, the following hypothesis stated in its alternative form is tested by the study:

H1: Operating cash flows are better than operating net income in explaining dividend changes.

The relationship between cash flows and dividend policy may be affected by the firm's investment opportunities. On the one hand, firms that have future investment opportunities 
are more expected to retain their cash flows instead of paying dividends. This is so because as future investment opportunities grow, the expected return on these investment opportunities becomes higher. Thus, the firm might give a priority to its investment opportunities are limited, the likelihood of paying dividends increases. Consistent with this reasoning, Gaver and Gaver found that a firm's dividend yield is negatively associated with its growth opportunities.

Based on the above, the following hypothesis stated in its alternative form is tested by the study:

H2: Operating cash flows are better than operating net income in explaining dividend changes for firms with low growth prospects than for firms with high growth prospects.

\section{Methodology and development of hypotheses}

\subsection{Sample Selection}

The following criteria are employed to select the sample of firms used in this study:

(1) annual reports for the period 2010-2016 must be available for each firm included in the study; (2) the firm must belong to the industrial sector; (3) cash dividends are not zero for the year under examination; (4) market value of equity (market capitalization), and market value per share must be available at the calendar - year end for each firm throughout the period 1992-1998. Forty-two industrial firms listed on the Amman Stock Exchange met these criteria. The observations collected from these firms were checked for the presence of outliers, and these were subsequently removed from the analysis. The final set included 164 firm/year observations.

\subsection{Measurement of Variables}

Measures of the variables used by this study are similar to those employed by pervious studies. The definitions of these measures are as follows:

(1) Dividend changes are measured as cash dividend per share for the current year minus cash dividend per share for the past year divided (deflated) by the beginning of the year market price per share.

(2) Operating income is measured as a net income before extraordinary and non- operating items for the year divided by the beginning of the year market capitalization.

(3) Operating cash flows are measured by adjusting operating income for non-cash expenses (e.g., depreciation) and for changes in working capital accounts related to operations with the exception to changes in cash and marketable securities divided by the beginning of the year market capitalization.

(4) Lagged dividends are measured by the previous year dividends deflated by a firm's market capitalization.

(5) Growth prospect is measured by dividing market capitalization plus the book value of the debt by the book value of the total assets. 


\section{Macrothink}

Asian Journal of Finance \& Accounting

ISSN 1946-052X

2020, Vol. 12, No. 2

The use of market values as deflators is preferable because they avoid the bias inherited in historical cost measures. In addition, a firm's dividend policy is usually driven by market performance rather than by book values.

\subsection{Empirical Model}

To examine the relationship between operating cash flows and dividend changes, the researcher used multiple regression analysis. The analysis is conducted at two levels. At the first level this relationship is examined for the entire sample of firms using pooled cross sectional /time series regression during the period 2010-2016, while at the second level, the relationship is tested after dividing the sample into two groups; high growth firms versus low growth firms. Building on multivariate analysis, the regression model is:

$$
\mathrm{ADIV}_{\text {it }}=\mathrm{B}_{0}+\mathrm{B}_{1} \mathrm{OPCF}_{\text {it }}+\mathrm{B}_{2} \mathrm{OPNI}_{\mathrm{it}}+\mathrm{B}_{3} \mathrm{LDIV}_{\mathrm{it}}+\mathrm{e}_{\mathrm{it}}
$$

Where:

$$
\begin{aligned}
& \operatorname{ADIV}_{\text {it }}=\text { change in dividends for firm-year } i \text { in time } t \text {, } \\
& \mathrm{OPCF}_{\text {it }}=\text { operating cash flows for firm-year } i \text { in time } t \text {, } \\
& \mathrm{OPNI}_{\mathrm{it}}=\text { operating Net Incone for firm-year } i \text { in time } t \text {, } \\
& \mathrm{LDIV}_{\mathrm{it}} \quad=\text { lagged dividends for firm-year } i \text { in time } t-1 \text {, } \\
& \text { eit }=\text { error term, } \\
& \mathrm{B}_{1}=\text { the regression coefficients } \mathrm{m}, \mathrm{i}=0,1,2,3
\end{aligned}
$$

The above regression model is used to estimate the coefficients of the variables. The purpose of this model is to test whether the variable operating cash flow contributes significantly and positively to the predictions of dividend changes given the operating net income.

\section{Data analysis, results/interpretation and discussion of findings}

\subsection{Descriptive Statistics}

Table (1), Panel A presents a summary of the statistics of the variables used in the study for the full sample. As seen from the Table, the mean of the dividend changes variable (ADIV) (normalized by market price per share) is 0.0046 with a high standard deviation indicating that there is a considerable variation in dividend changes among the 164 firm/year observations. It can also be seen that the mean of the operating cash variable exceeded that of the operating net income variable although the difference is not statistically significant at the $5 \%$ level. However, the standard deviation of the operating cash flows variable is much higher than that of the operating net income variable. This is consistent with the notion that the operating cash flow is deemed a noisier measure of performance compared with the operating income.

Panels B and C of Table (1) present descriptive statistics of the variables of the study after the researcher had divided the sample of firms into a low growth firms and high growth firms according to market to book value ratio. As seen, the low growth firms have a lower average 
operating net income and operating cash flows compared to those of the high growth firms. It can also be noted that the changes in dividends (ADIV), though negative, is higher for the low growth firms than that for the high growth firms. Finally, it is worth mentioning that the mean OPCF is higher than the mean OPNI for the high growth firms, while the mean OPNI is higher than the mean OPCF for the low growth firms. This suggests that on average the higher operating cash flows compared to operating net income, the better the market performance of the firm as reflected by the market to book value ratio.

Table 1. Descriptive statistics

Panel A: Full sample $(n=164)$

\begin{tabular}{lllll}
\hline & Mean & St. Deviation & Minimum & Maximum \\
\hline ADIV & -.0046 & .0488 & -.3395 & .4139 \\
OPCF & .0963 & .3196 & -2.309 & 1.926 \\
OPNI & .0732 & .0963 & -.3994 & .4220 \\
LDIV & .0308 & .0240 & 0 & .1340 \\
GP & 1.2687 & .6018 & .2620 & 3.795 \\
\hline
\end{tabular}

Panel B: Low growth firms $(\mathbf{n}=82)$

\begin{tabular}{lllll}
\hline & Mean & St. Deviation & Minimum & Maximum \\
\hline ADIV & -.0054 & .0648 & -.3395 & .4139 \\
OPCF & .0581 & .3740 & -2.3099 & 1.0390 \\
OPNI & .0724 & .1142 & -.3994 & .4220 \\
LDIV & .0286 & .0246 & 0 & .1340 \\
GP & .8410 & .2490 & .2620 & 1.198 \\
\hline
\end{tabular}

Panel C: High growth firms $(n=82)$

\begin{tabular}{lllll}
\hline & Mean & St. Deviation & Minimum & Maximum \\
\hline ADIV & -.0029 & .0212 & -.1020 & .0444 \\
OPCF & .1281 & .2477 & -.5281 & 1.9263 \\
OPNI & .0839 & .0745 & -.1386 & .3469 \\
LDIV & .0331 & .0232 & 0 & .1020 \\
GP & 1.7085 & .5377 & 1.200 & 3.795 \\
\hline
\end{tabular}

Where:

ADIV : change in dividends

OPCF: operating cash flows

OPNI : operating net income

LDIV : lagged dividends

GP : growth prospects (market to book value)

\subsection{Regression Results}

\subsubsection{Testing $\mathrm{H}_{1}$}




\section{Mll Macrothink}

Asian Journal of Finance \& Accounting

ISSN 1946-052X

2020, Vol. 12, No. 2

Hypothesis One states that operating cash flows are better than operating net income in explaining dividend changes. This hypothesis was examined by regressing the dependent variable, dividend changes on the independent variables, operating cash flows, operating net income and lagged dividends. Panel (1) of Table (2), repots the results of the regression model. As can be seen, the regression model is highly significant $(F=23.432)$ and can explain $32 \%$ (Adj. $R^{2}=.3185$ ) of the variation in dividend changes for the 164 firm-year observations. Both operating net income and lagged dividends are statistically significant at the $1 \%$ level. While, the coefficient of the operating net income is positive, the coefficient of the lagged dividend is negative. These results are consistent with previous studies, suggesting that operating net income is an important determinant of a firm's dividend policy. The coefficient of the operating cash flows is positive as hypothesized, though asignificant at the conventional level of $5 \%$. The mean coefficient of the operating net income is gteater than that of the operating cash flows suggesting that the operating Net tacome has incremental information beyond operating cash flows in explaining dividend changes.

The above model was checked for the presence of multicollinearity among the independent variables. A correlation matrix incorporating all the variables was run (see Table 3). As can be seen, the correlation coefficient between each pair of the independent variables, particularly between the OPCF variable and the OPNI variable is low, suggesting that the results of the above regression model are not affected by multicollinearity.

However, to explore the matter further, the researcher gives Panel (2) of Table (2) which repots the regression results after excluding the operating net income from the original model whereas Panel (3) of the table reports these results after excluding the operating cash flow from the original model. As can be seen form Panel (2), the regression model incorporating the operating cash flows and lagged dividends is significant and can explain an out $14 \%$ of the variation in the dividend changes. The coefficient of the operating cash was insignificant. Compared with these result, the model incorporating operating income and lagged dividends can explain about $32 \%$ the variation in the dividend changes, and the variable operating net income is highly significant.

Table 2. Cross sectional regression results using 164 firm-year observations for the period 1997-2002

\section{Panel (1)}

\begin{tabular}{llllll}
\hline $\mathrm{B}_{0}$ (Constant) & $\mathrm{B}_{1}(\mathrm{OPCF})$ & $\mathrm{B}_{2}(\mathrm{OPNI})$ & $\mathrm{B}_{3}(\mathrm{LDIV})$ & $\mathrm{Adj} . R^{2}$ & $F$ \\
\hline $.0101^{* *}$ & .0081 & $.1525^{* * *}$ & $-.6915^{* * *}$ & .3185 & $23.435^{* * *}$ \\
$(2.602)$ & $(1.095)$ & $(6.094)$ & $(-6.923)$ & & \\
\hline
\end{tabular}

Panel (2)

\begin{tabular}{llllll}
\hline $\mathrm{B}_{0}($ Constant $)$ & $\mathrm{B}_{1}(\mathrm{OPCF})$ & $\mathrm{B}_{2}(\mathrm{OPNI})$ & $\mathrm{B}_{3}(\mathrm{LDIV})$ & $\mathrm{Adj} . R^{2}$ & $F$ \\
\hline $.0163 * * *$ & .0022 & & $-.5474 * * *$ & .1451 & $13.219^{* * *}$ \\
$(3.913)$ & $(.793)$ & & $(-5.036)$ & & \\
\hline
\end{tabular}

Panel (3) 


\begin{tabular}{llllll}
\hline $\mathrm{B}_{0}$ (Constant) & $\mathrm{B}_{1}(\mathrm{OPCF})$ & $\mathrm{B}_{2}(\mathrm{OPNI})$ & $\mathrm{B}_{3}(\mathrm{LDIV})$ & $\mathrm{Adj} . R^{2}$ & $F$ \\
\hline $.0100^{* *}$ & & $.1489 * * *$ & $-.7040^{* * *}$ & .3175 & $34.501^{* * *}$ \\
$(2.591)$ & & $(5.997)$ & $(-7.090)$ & & \\
\hline
\end{tabular}

$\mathrm{B}_{0}-\mathrm{B}_{3}$ : regression coefficients

$\mathrm{t}$ - values are between parentheses

$* * *$ significant at $1 \%$

** significant at $5 \%$

Table 3. Correlation matrix

\begin{tabular}{lllll}
\hline Variable & ADIV & OPCF & OPNI & LDIV \\
\hline ADIV & 1.00 & & & \\
& $(.)^{*}$ & & & \\
OPCF & .080 & 1.00 & & \\
& $(.170)$ & $()$. & & \\
OPNI & .298 & .164 & 1.00 & 1.00 \\
& $(.001)$ & $(.024)$ & $()$. & $()$. \\
LDIV & -.396 & .151 & .217 & $(.011)$ \\
& $(.000)$ & $(.035)$ & & \\
\hline
\end{tabular}

* denotes significance level.

To sum up, the results of the regression analysis indicate that the operating net income and lagged dividend are significantly associated with dividend changes. In addition, operating cash flows have no incremental information content beyond the operating net income in explaining dividend changes. Therefore, the null hypothesis of $\mathrm{H} 1$ cannot be rejected.

\subsubsection{Testing $\mathrm{H}_{2}$}

The above results could be attributed to our assumption that the relation between cash flow and dividend changes is linear across the firms. However, this assumption may not hold for all firms. As discussed earlier in the study, the information content of cash flows versus accruals might be firm-, industry-, and /or situation- specific. While this study has taken into account the industry factor by concentrating only on the industrial firms listed on the Amman Stock Exchange, an attempt is here made to examine the impact of the firm's growth prospects on the incremental information of cash flows. Firms with high growth prospects are more expected to retain their cash flows than those firms with low growth prospects do. To examine this, the firm/ year observations were divided into tow groups according to their growth prospects (as measured by market to book value). Panel A of Table (4) reports the regression results for the low growth group, while panel B of the table reports those results of the high growth group. As for the low growth group (see Panel A of Table 4), the model is highly significant $(\mathrm{F}=13.752, \mathrm{p}=.0001)$ and can explain about $34 \%$ of the dividend changes. Similar to the results reported in Table (2) above, both OPNI and LDIV are highly significant with positive and negative coefficients, respectively. The OPCF variable is significant though at $10 \%$. Similar results are also reported for the high growth group (see panel B). Both OPNI and LDIV are found significant at $1 \%$ with positive and negative suggest that the OPNI has 
incremental information beyond OPCF in explaining dividend changes for both the low growth group and high growth group.

Table 4. Summary results of the regressions for the low growth firms and high growth firms

Panel A: Low growth firms

\begin{tabular}{llllll}
\hline $\begin{array}{l}\mathrm{B}_{0} \\
(\text { Constant }\end{array}$ & $\mathrm{B}_{1}(\mathrm{OPCF})$ & $\mathrm{B}_{2}(\mathrm{OPNI})$ & $\mathrm{B}_{3}(\mathrm{LDIV})$ & Adj. $R^{2}$ & $F$ \\
\hline .0087 & $.0154 *$ & $.1378^{* * *}$ & $-.6699 * * *$ & .3437 & $13.572 * * *$ \\
$(1.658)$ & $(1.742)$ & $(4.671)$ & $(-4.863)$ & & \\
\hline
\end{tabular}

Panel B: High growth firms

\begin{tabular}{llllll}
\hline $\begin{array}{l}\mathrm{B}_{0} \\
(\text { Constant }\end{array}$ & $\mathrm{B}_{1}(\mathrm{OPCF})$ & $\mathrm{B}_{2}(\mathrm{OPNI})$ & $\mathrm{B}_{3}(\mathrm{LDIV})$ & $\mathrm{Adj} . R^{2}$ & $F$ \\
\hline .0052 & -.0135 & $.1252 * * *$ & $-.5904 * * *$ & .4121 & $17.361^{* * *}$ \\
$(1.501)$ & $(-1.520)$ & $(4.082)$ & $(-6.488)$ & & \\
\hline
\end{tabular}

$\mathrm{B}_{0}-\mathrm{B}_{3}$ : regression coefficients

$\mathrm{t}$ - values are between parentheses

*** significant at $1 \%$

* $\quad$ significant at $10 \%$

\section{Conclusion, recommendations}

The main objective of this study was to examine whether operating cash flows have incremental information beyond the operating net income in explaining dividend changes for a sample of Jordanian industrial firms listed on the ASE during the period 2010-2016. arguments for the operating cash flow information suggest that it is better than the accrual net income in reflecting the firm performance, and in measuring the firm liquidity. Both performance and liquidity are viewed as significant factors in influencing a firm's dividend policy. However, the results of this study do not render support to the asserted relationship between operating cash flows and dividend changes. The study found that the operating cash flows do not provide any incremental information beyond that provided by the accrual operating income. These results are consistent with those of the previous studies.

Previous research on the information content of cash flows versus accrual income assumes linear relations between cash flows and dividend changes. Following Charitou and Vafeas, this study allowed nonlinearity in the relationship between cash flow and dividend changes 
by using separate models for high growth firms and low growth firms. The results of the tow regression models provide evidence consistent with the superiority of the accrual operating income over the operating cash flow in explaining dividend changes.

The results of this study suggest that Jordanian industrial firms base their dividend polices on accrual income rather than on operating cash flows. According to Lawson, paying dividends should be based on cash flows rather than accrual earnings. He stated that basing dividend policy on accrual income would result in dividend payments that are not internally financed and, in effect, this would deteriorate the liquidity and solvency position of the firm.

\section{References}

Ali, A. (Spring, 1994). The Incremental Information Content of Earnings, Working Capital From Operations, and Cash Flows. Journal of Accounting Research, 61-74. https://doi.org/10.2307/2491387

Andreas Charitou, \& Nikos Vafeas. (1998). The Association Between Operating Cash Flows and Dividend Changes: An Empirical Investigation. Journal of Business Finance and Accounting, 225-249. https://doi.org/10.1111/1468-5957.00185

Baker, H. (Autumn, 1985). Survey of Management Views on Dividend Policy. Financial Management, 78-84. https://doi.org/10.2307/3665062

Benartzi, S., \& R. Michaely. (July, 1997). Do Changes in Dividends Signal the Future or the Past?. Journal of Finance, 1007-1034. https://doi.org/10.1111/j.1540-6261.1997.tb02723.x

Bernard, V.L. and T.Stober. (October, 1989). The Nature and Amount of Information in Cash Flows and Accruals. The Accounting Review, pp. 624-652.

Bernstein, A.L. (1993). Financial Statement Analysis, Fifth Edition, Homewood, IL: Irwin.

Bernstein, A.L., \& J.J. wild. (1998). Financial Statement Analysis: Theory. Application, and Interpretation, Sixth Edition, McGraw-Hill, NY.

Bowen, R. M., D. Burgstahler, \& L. A. Daley. (October, 1987). The Incremental Information Content of Accrual Versus Cash Flows. The Accounting Review, 723-747.

Brook, Y., Jr. Charlton, W.T. Chalrton, \& R.J. Hendershott. (Autumn, 1998). Do Firms Use Dividends to Signal Large Future Cash Flow Increases?. Financial Management, 46-58. https://doi.org/10.1111/1468-5957.00185

Caritou, A. and N. Vafeas. (Januray/March, 1998). The Association Between Operating Cash Flows and Dividend Changes: An Empirical Investigation. Journal of Business Finance and Accounting, 225-249. https://doi.org/10.1111/j.1468-5957.1994.tb00337.x

Dechow, P.M. (July,1994). Accounting Earnings and Cash Flows as Measures of Firm Performance: The Role of Accounting Accruals. Journal of Accounting and Economics, 3-42. https://doi.org/10.1016/0165-4101(94)90016-7 
Ettredge, M., \& J.Y.Kim. (Fall, 1994). Dividend Behavior Surrounding LIFO Adoption. Review of Financial Economics, 39-54. https://doi.org/10.1016/1058-3300(94)90004-3

Financial Accounting Standard Board (FASB). (1980). Summary of the Discussion Memorandum on Reporting funds Flows. Liquidity, and Financial Flexibility. Stamford, CT: FASB.

Gaver, J., \& K. Gaver. (1993). Additional Evidence on the Association Between the Investment Opportunity Set and Corporate Financing, Dividend, and Compensation Policies. Journal of Accounting and Economics, 16, 126-161. https://doi.org/10.1016/0165-4101(93)90007-3

Gibson, C.H. (1995). Financial Statement Analysis: Using Financial Accounting Information, Sixth Edition, South-Western College Publishing, Ohio, USA.

Hagerman, R.L., \& R.J. Huefner. (Spring, 1980). Earnings Numbers and Dividend Prediction. Review of Business and Economic Research, 39-48.

Ibid, Hagerman, \& Huefiner. (1980). BOOK REVIEWS, Jewish Education, 48(4), 39-48. https://doi.org/10.1080/0021642800480408

Ibid, Lawson. (1996). The measurement of the economic performance of the US Nonfinancial Corporate Business Sector 1946-1990: an application of the shareholder value creation concept. European Accounting Review, 5(4), 715-741. https://doi.org/10.1080/09638189600000044

Kathleen Simons. (1994). THE RELATIONSHIP BETWEEN DIVIDEND CHANGES AND CASH FLOW: AN EMPIRICAL ANALYSIS. Journal of Business Finance and Accounting, 577-587. https://doi.org/10.1111/j.1468-5957.1994.tb00337.x

Lawson, M. C. (1996). The Measurement of the Economic Performance of the US Nonfinancial Corporate Business Sector 1946-1990: An Application of the Shareholder Value Creation Concept. European Accounting Review, 5(4), 715-741. https://doi.org/10.1080/09638189600000044

Lintner, J.V. (May, 1956). Distribution of Incomes of Corporations Among Dividends, Retained Earnings, and Taxes. American Econmic Review, 97-113.

Lipson, M., C. Macquieira, \& W. Megginson. (Autumn, 1998). Dividend Initiation and Earnings Surprises. Financial Management, 36-45. https://doi.org/10.2307/3666273

MERTON H. MILLER, \& KEVIN ROCK. (1985). Dividend Policy under Asymmetric Information, The journal of Finance, $\quad$ TL(4), 37-61. https://doi.org/10.1111/j.1540-6261.1985.tb02362.x

Pruitt, S.W., \& L.J. Gitman. (August, 1991). The Interactions Between the Investment, Financing, and Dividend Decisions of Major U.S.Firms. Financial Review, 409-430. https://doi.org/10.1111/j.1540-6288.1991.tb00388.x 


\section{Macrothink}

Asian Journal of Finance \& Accounting ISSN 1946-052X 2020, Vol. 12, No. 2

Rayburn, J. (1986). The Association of Operating Cash Flow and Accruals with Security Returns. Journal of Accounting Research, 24, 112-133. https://doi.org/10.2307/2490732

Simons, K. (June,1994). The Relationship Between Dividend Changes and Cash Flow: An Empirical Analysis. Journal of Business Finance and Accounting, 577-587.

Simons, K. (June,1994). The Relationship Between Dividend Changes and Cash Flow: An Empirical Analysis. Journal of Business Finance and Accounting, 577-587.

Sloan, R.G. (July,1996). Do Stock Prices Fully Reflect Information in Accruals and Cash Flows About Future Earnings. The Accounting Review, pp.289-315.

White, G. I., A. C. Sondhi, \& D. Fried. (Januray/March, 1998). The Analysis and Use of Financial Statements, Second Edition, John Wiley \& Sons, Inc., New York (1997). 